\title{
Youth unemployment and psychological distress in the Republic of Ireland
}

\author{
Damian F. Hannan, Sean O Riain and Christopher T. Whelan
}

\begin{abstract}
U nemployment is the most significant influence on the levels of psychological distress of young adults. Unlike the situation for the adult population, social class and income are not contributory factors. Social class of origin, however, does have a contributory effect. Feelings of lack of control and attribution of responsibility for employment solely to structural or political factors increase the impact of unemployment. Evidence in relation to employment commitment does not support "culture of poverty" type explanations. U nemployed youth appear to be "people with a problem" rather than "problem people".
\end{abstract}

(c) 1997 The A ssociation for Professionals in Services for A dolescents

\section{Introduction}

In this paper we examine the psychological consequences of youth unemployment and develop some understanding of the processes involved by drawing on data from two nationally representative studies conducted in the Republic of Ireland in 1987; one dealing with young adults and the other with the population as a whole. Both of these studies are cross-sectional and, as is well known, comparisons of people who are at the time of study unemployed with similar people who are in paid work gives rise to the possibility that differences in levels of psychological distress may be accounted for by the operation of prior characteristics independent of employment status (V aillant and V aillant, 1981; Feather and 0 'Brien, 1986). This interpretation is a great deal more plausible during periods of very low unemployment where personal characteristics might be thought to impede job-getting. W hen unemployment rates are high, however, it is more likely that the observed differences arise primarily from decrements in mental health occurring after job loss (W arr, 1985, 1987). This certainly seems likely to be the case in the Republic of I reland where by 1987 the unemployment rate was $18 \%$ and the unemployment rate for 1982 school-leavers in their first year out of school was cl ose to $40 \%$ and remained as high as 17\% for 5 years after leaving school (Breen et al., 1990; W helan, 1996). In the light of these figures and evidence from longitudinal studies relating to outcomes of the kind that we are concerned with, we will operate in what follows with the assumption that the dominant direction of causality is from unemployment to psychological distress (Jackson et al., 1983; Liem, 1987; W arr, 1987; Kessler et al., 1989).

W hile the available data do have some limitations they also offer significant advantages in that we are able to take into account not only the role of unemployment but also that of social class, income and the manner in which personal and social resources mediate between such factors and psychological distress. This opportunity is particularly valuable

Reprint requests and correspondence should be addressed to D. F. H annan, The Economic and Social Research Institute, Dublin, I reland, 4 Burlington Road, Dublin 4, Republic of I reland. 
because of the relative neglect of issues relating to the role of social class and poverty in the literature dealing with the impact of unemployment.

\section{Data}

In pursuing our objectives we will draw on two main sources of data. The first data set is based on extensive interviews with a national sample of 1982 school-leavers who were interviewed in 1987, 5 years after they had completed their second level education. A that stage $90 \%$ of the sample were aged between $20-24$. Of the original sample of 1940 , on whom basic sociodemographic and labour market information was collected, $85 \%$ were traced (Breen, 1991; H annan and Shortall, 1991; H annan and O 'Riain, 1993). The second source of data is a national survey of households conducted in 1987. The survey was designed to give a national sample of the population. A household response rate of $64.3 \%$ was achieved and re-weighting procedures were at the household level and the individuals within the household (C allan et al., 1989; W helan, 1992a).

\section{Psychological distress and the unemployment of young people}

Young people are different from unemployed adults in a number of ways. They have, for instance, less financial strains and role pressures than the married middle aged. However, they do face a series of very problematic role transitions which may be associated with increased distress. In addition, employment provides a critical gateway to other transitions.

The deprivations associated with unemployment are, at least in part, socially constructed and culturally variable. There are a number of ways in which different social groups can suffer to a greater or lesser extent from: exposure to unemployment, vulnerability, and economic hardship (W helan et al., 1991). Clearly some social groups are much more at-risk of unemployment. Vulnerability refers to how individuals in a group typically respond to the experience of unemployment. A nother important aspect is the economic hardships and financial strain caused by unemployment which have been shown to have a strong detrimental effect on psychological health both among the population as a whole (W helan, 1992a) and among young people (Ullah, 1990). However, this effect may be somewhat weaker among young people as they tend to have less financial commitments and responsibilities (W arr and Jackson, 1984; O 'B rien, 1986; W arr, 1987).

$\mathrm{On}$ the other hand, psychological effects may become serious amongst young people in their developmental process of assuming adult statuses/roles. The late adolescent development stage is frustrated by unemployment since so much of adult identity and status is founded on achieving an independent occupation or employment status (G urney, 1980; Donovan and Oddy, 1982). W arr (1987) argues that while unemployment does damage to young people's affective well-being it is the social role of autonomy, competence and aspirations which should be of greatest concern. Lack of money and independent accommodation decrease autonomy, and competence is impaired by the lack of learning activity and challenges. U nemployment has also been hypothesised to "desocialise" young people and create a "culture of unemployment" and alienation which could have serious long-term consequences.

A useful starting point for constructing a model of the psychological effects of 
unemployment is to view the concept of stress itself as having three major conceptual domains (Pearlin et al., 1981). These are the sources of stress, the mediators of stress and the manifestations of stress. Here we focus on unemployment as a source of stress. The mediators of stress are diverse and their effects on the psychological impact of unemployment can be complex. A mong the most important mediators are the social and material commitments of the individual concerned, such as the extent of their role commitments, and the degree of financial strain; and personal values and orientations such as commitment to employment, feelings of personal control or powerlessness and the individual's causal attributions for unemployment- or the extent to which young people blame themselves or "the system" for their unemployment.

The manifestations of stress are taken in this study to be "psychological distress" and we use a slightly modified version of the 12 -item form of the $\mathrm{G}$ eneral $\mathrm{H}$ ealth Q uestionnaire to assess the levels of this distress (G oldberg, 1972).

\section{Young people and psychological distress: a first look}

W e will present our results relating to psychological distress in two slightly different forms. The first simply gives variation in G HQ scores ranging from a minimum of 0 to a maximum of 12 . The second form of presentation sets out the percentage of people scoring above a threshold score of 2 which is the cut-off point for estimation of the likelihood that an individual would be classed as a non-psychotic psychiatric case. The initial evidence suggests that young people suffer less from psychological distress than the adult population at large; $11.6 \%$ of the sample scored above the threshold compared to $17 \cdot 1 \%$ for the adult population. In Table 1 we show the impact of employment status on psychological distress.

Table 1 Labour force status (in 1987) and psychological distress

\begin{tabular}{|c|c|c|c|c|c|}
\hline \multirow[t]{2}{*}{ Labour force status } & \multicolumn{2}{|c|}{$\begin{array}{l}\text { Percentage above } \\
\text { GHQ threshold }\end{array}$} & \multicolumn{2}{|c|}{ M ean GHQ score } & \multirow{2}{*}{$\begin{array}{l}\text { Percentage of } \\
\text { young people } \\
\text { in this status* } \\
\text { (by 1987) }\end{array}$} \\
\hline & $\begin{array}{l}\text { School- } \\
\text { leavers }\end{array}$ & A dultst & $\begin{array}{l}\text { School- } \\
\text { leavers }\end{array}$ & A dultst & \\
\hline $\begin{array}{l}\text { Employed } \\
\text { Students (full-time) } \\
\text { H ome duties } \\
\text { U nemployed, previously held job } \\
\text { Looking for first job }\end{array}$ & $\begin{array}{r}7 \cdot 0 \\
10 \cdot 2 \\
16 \cdot 3 \\
28 \cdot 6 \\
23 \cdot 2\end{array}$ & $\begin{array}{c}7 \cdot 4 \\
- \\
22 \cdot 0 \\
36 \cdot 6 \\
25 \cdot 7\end{array}$ & $\begin{array}{l}0.48 \\
0.53 \\
0.96 \\
1.93 \\
1.52\end{array}$ & $\begin{array}{l}0 \cdot 54 \\
- \\
1 \cdot 36 \\
2 \cdot 20 \\
1 \cdot 72\end{array}$ & $\begin{array}{r}71 \cdot 9 \\
2 \cdot 4 \\
5 \cdot 0 \\
16 \cdot 6 \\
2 \cdot 6\end{array}$ \\
\hline $\begin{array}{r}\text { Total } \% \\
(n)\end{array}$ & $\begin{array}{l}11 \cdot 6 \\
(1134)\end{array}$ & $\begin{array}{l}17 \cdot 8 \\
(6089)\end{array}$ & $\begin{array}{c}0.79 \\
(1134)\end{array}$ & $\begin{array}{r}1 \cdot 18 \\
(6089)\end{array}$ & $\begin{array}{l}98 \cdot 5 \\
(1134)\end{array}$ \\
\hline T ests of significance* & \multicolumn{2}{|c|}{$\begin{array}{l}\mathrm{Chi}^{2}=76 \cdot 5 \\
\mathrm{df}=5 \\
\mathrm{p}<0.0001\end{array}$} & \multicolumn{2}{|c|}{$\begin{array}{l}\text { Eta }^{2}=0 \cdot 117 \\
F(5,1028)=18.65 \\
p<0.0001\end{array}$} & \\
\hline
\end{tabular}

*This column does not add up to $100 \%$ because those on employment or training schemes and those with long-term illnesses are not included due to their small numbers. T ests of significance are based on the whole table, including the residual category.

†Source: Whelan et al., 1991, p. 34. 
W orking for pay and profit is clearly the most desirable status with a very low level of distress. The vast majority of young people (72\%) are in this group and only one in 20 display even one symptom of distress in the GH Q. Full-time students show slightly greater levels of distress. Being a student is basically a reasonably stress-free occupation. Those in "home duties" show levels of distress well above the average and over twice as high as those working for pay and profit. The most distressed group are the unemployed with those who held a job at some stage being the most damaged. 0 ver one in four of the unemployed are above the threshold score.

O verall, in fact, the pattern of results mirrors almost exactly those found by Whelan et al. (1991) for the adult population as a whole. Furthermore, in both adult and youth samples, particularly for men, it was the brute fact of unemployment which was of paramount importance rather than factors such as length of unemployment or previous employment experience (W inefield and Tiggemann, 1989a, b). The average difference in GHQ scores between the unemployed and those who had never got a job is not statistically significant.

The experience of unemployment in social context

Clearly certain social groups are exposed to higher risks of unemployment than others. In particular, the unemployed are likely to be disproportionately drawn from members of the lower social classes. Since one of the most consistently documented associations in psychiatric epidemiology is that between social class or socio-economic status and psychological distress the question arises of the extent to which the impact of unemployment arises because of the association with social class or vice versa (Kessler and Cleary, 1980; H obbs et al., 1985). The choice we are confronted with is illustrated by the fact that, in attempting to account for the higher rates of distress among lower-class people, research has been influenced by two contending perspectives: the social selection and social causation perspectives. The former argues that natural competitive conditions lead to the existing distribution of psychological distress across the class structure. The social causation argument emphasises the life condition to which lower class people are exposed.

In short then the contending hypotheses are: (1) that one's mental state helps determine his social position; and (2) that one's social position helps determine his mental state (Kessler and Cleary, 1980, p. 465).

In Ireland for both young adults and the population as a whole unemployment has been heavily concentrated in the working class (Breen, 1991; Whelan, 1996). Support for the social selection hypothesis would suggest that, rather than unemployment causing high levels of psychological distress, the situation is rather that those who have been selected into the working class on psychological grounds also have a high probability of being found in the increasing ranks of the unemployed. The most plausible form of the argument, as Kessler and Cleary (1980) note, is that the factors which influence ability to compete for social position overlap with those which influence ability to cope with stress. The explanation is one which involves reference to "constitutional frailty" because it emphasises intrapsychic propensities to distress rather than environmental influences (Kessler, 1979). The hypothesis can be tested by examining the extent to which the pattern of social fluidity of those who are currently psychologically distressed differs from that of those who are not experiencing such distress. W helan (1994) showed that for the Irish adult population when 
appropriate allowance is made for the group differences in origins and destinations, as suggested by Fox (1990), no evidence could be found of departures from expectation in the direction predicted by the social selection model.

Within the social causation perspective two rather distinct views have been expressed regarding the manner in which the objective conditions of lower-class life influence levels of psychological distress. The first view holds that greater exposure to stressful life experiences accounts for the observed relationship between social class and psychological distress. The alternative view, while emphasising the importance of life experiences, focuses attention on the manner in which the environment shapes social and intrapsychic resources, thus influencing ones coping repertoire (M cLeod and Kessler, 1990).

A s is clear from Table 2, Whelan et al. (1991), in the study of the adult population in I reland, found a strong relationship between social class and levels of psychological distress; with a particularly striking contrast between the manual and non-manual groups. The results of Whelan's (1994) analysis demonstrated that the major factors leading those located in the lower classes to experience high levels of distress are their greater exposure to unemployment and economic deprivation; in particular exposure to deprivation of an extreme kind which involves the enforced absence of necessities such as food, clothing and heat.

For our school-leavers samples, on the other hand, there is no clear relationship to their current social class (i.e. for those employed). Of course, for the unemployed stress levels are very high (T able 1 ). For adults social class reflects an accumulated set of experiences which influence the accumulation and erosion of resources and the prospects of such further experiences. For younger people, on the other hand, their current class situation (is occupational status) may be considerably less permanent and a relatively poor predictor of life-style and resources- with around half still living in the parental home for instance. If

Table 2 GH Q scores by social class of origin and current status

\begin{tabular}{|c|c|c|c|c|c|c|}
\hline \multirow[t]{2}{*}{ Social class } & \multicolumn{3}{|c|}{ Percentage above G H Q threshold } & \multicolumn{3}{|c|}{ M ean GHQ score } \\
\hline & $\begin{array}{c}\text { School- } \\
\text { leavers } \\
\text { (Father's } \\
\text { occupation) }\end{array}$ & $\begin{array}{l}\text { School- } \\
\text { leavers } \\
\text { (own } \\
\text { occupation) }\end{array}$ & A dultst & $\begin{array}{c}\text { School- } \\
\text { leavers } \\
\text { (Father's } \\
\text { occupation) }\end{array}$ & $\begin{array}{l}\text { School- } \\
\text { leavers } \\
\text { (own } \\
\text { occupation) }\end{array}$ & A dults \\
\hline $\begin{array}{l}\text { U pper middle class } \\
\text { M iddle class } \\
\text { Lower middle class } \\
\text { U pper working class } \\
\text { W orking class } \\
\text { Lower working class }\end{array}$ & $\begin{array}{r}12 \cdot 8 \\
8 \cdot 0 \\
6 \cdot 3 \\
14 \cdot 6 \\
9 \cdot 7 \\
18 \cdot 5\end{array}$ & $\begin{array}{l}8 \cdot 1 \\
5 \cdot 7 \\
8 \cdot 7 \\
3 \cdot 5 \\
8 \cdot 3 \\
2 \cdot 9\end{array}$ & $\begin{array}{r}8 \cdot 1 \\
10 \cdot 8 \\
13 \cdot 4 \\
19 \cdot 3 \\
19 \cdot 3 \\
23 \cdot 2\end{array}$ & $\begin{array}{l}0.82 \\
0.64 \\
0.56 \\
0.94 \\
0.59 \\
1.22\end{array}$ & $\begin{array}{l}0.39 \\
0.37 \\
0.61 \\
0.33 \\
0.56 \\
0.47\end{array}$ & $\begin{array}{l}0.57 \\
0.72 \\
0.86 \\
1.19 \\
1.26 \\
1.58\end{array}$ \\
\hline $\mathrm{n}$ & 1078* & $817 *$ & 5726 & 1078* & $817 *$ & 5726 \\
\hline $\begin{array}{l}\text { Chi-square } \\
\text { df } \\
p \\
\text { Pearson'sr }\end{array}$ & $\begin{array}{c}18.7 \\
5 \\
<0.01 \\
0.07\end{array}$ & $\begin{array}{c}6.3 \\
5 \\
\text { n.s. } \\
-0.02\end{array}$ & & $\begin{array}{c}\mathrm{Eta}^{2}=0.02 \\
F=4 \cdot 1 \\
(5,1072) \\
p=<0.01\end{array}$ & $\begin{array}{c}0.033 \\
26.3 \\
(5,811) \\
<0.01\end{array}$ & \\
\hline
\end{tabular}

*Social class of origin includes those unemployed or still in school etc.; current occupational status does not.

†Source: Whelan et al., 1991, pp. 28-29. 
we focus on class origins - and, in this case include the unemployed - as indexed for father's occupation, however, a somewhat clearer relationship emerges. Thus there is a significant difference between those from manual class backgrounds ( $14.4 \%$ being above the GHQ threshold) and those from non-manual backgrounds ( $8.3 \%$ above the GHQ threshold). The class relationship, however, is not linear as it is in the adult population.

The relationship between social class and mental health is, therefore, less clear among young people. In order to develop our understanding of why this is so we need to examine the interaction between social class and employment status. The higher level of distress displayed by those from manual backgrounds is, undoubtedly, to some extent due to their greater exposure to the risk of unemployment. There is, however, also the possibility that those from lower social classes may be more vulnerable to the impact of unemployment due perh aps to a lack of coping resources or different attitudes to work. In Table 3 we set out the overall relationship of social class of origin and employment status to psychological wellbeing. (For the adult sample we focus on this current class position.)

For those in employment, both adults and school-leavers, class has little effect. H owever for those in the school-leavers sample who are unemployed a striking class effect emerges. A mong this group one in three of those from manual origins are above the GH Q threshold compared to less than one in five of those from non-manual backgrounds. This effect is even stronger among the adult unemployed. While unemployment appears to be almost equally distressing for the younger and older "manual" groups it was significantly less distressing for the non-manual respondents in the school-leavers' sample compared to their counterparts in the adult sample.

$H$ annan and ORiain (1993) show that, while young adults from manual backgrounds tend to spend longer periods unemployed, even if we discount this factor unemployment still appears to be more distressing for them. Equally, while they also tend to suffer more periods of unemployment, neither is this sufficient to explain away the class relationship. Clearly, certain additional, economic, social and psychological resources accrue to those from non-manual backgrounds which enable them to cope rather better with the stresses associated with unemployment. The nature of these resources will be explored in the subsequent sections of this paper.

Table 3 Psychological well-being by employment status and social class of origin (Father's occupation)

\begin{tabular}{|c|c|c|c|c|}
\hline \multirow[t]{3}{*}{ Father's occupational status } & \multicolumn{4}{|c|}{ Percent above GHQ threshold } \\
\hline & \multicolumn{2}{|c|}{ Employed } & \multicolumn{2}{|c|}{ Unemployed } \\
\hline & School-leavers & (A dults)* & School-leavers & (A dults)* \\
\hline $\begin{array}{l}\mathrm{M} \text { anual } \\
\mathrm{N} \text { on-manual }\end{array}$ & $\begin{array}{l}5.9 \\
7.2\end{array}$ & $\begin{array}{l}(8 \cdot 3) \\
(6 \cdot 5)\end{array}$ & $\begin{array}{l}32 \cdot 3 \\
19 \cdot 0\end{array}$ & $\begin{array}{l}(36 \cdot 6) \\
(29 \cdot 8)\end{array}$ \\
\hline & $\begin{array}{c}\mathrm{Chi}^{2}=0.46 \\
\mathrm{df}=1 \\
p=n . S .\end{array}$ & & $\begin{array}{c}\chi^{2}=4.02 \\
d f=1 \\
p<0.05\end{array}$ & \\
\hline
\end{tabular}

*Source: W helan et al., 1991, p. 47. 
Economic hardship and youth unemployment

A number of recent contributions to the literature on the effects of unemployment have drawn attention to the striking extent to which the role of economic deprivation has been neglected (Fryer, 1986, 1990; Whelan, 1992b). The evidence available from the limited number of empirical studies that have used multivariate analysis, when assessing the association between income and psychological health, indicates that the expected pattern of association between financial strain and psychological health during unemployment is found when using subjective measures of the former, but not when employing objectives measures (U Ilah, 1990). The evidence from the sample of young adults al so fits the pattern. W hile the net personal income of the unemployed was less than half that of those in employment there was no significant relationship between GHQ scores and income when employment status was entered as a set of dummy variables into the relevant regression. Dissatisfaction with income was strongly correlated with income with the unemployed whose expressed dissatisfaction was twice as likely to be above the GHQ threshold. However, in the absence of an understanding of how objective deprivation is related to perceptions of financial strain it is impossible to be sure that the direction of causality is not the opposite to that hypothesised. W helan (1992a), in an analysis of the Irish adult sample, has developed the argument that the suggestion that subjective measures of financial strain, but not objective measures, are related to psychological health does not provide a satisfactory basis for understanding the manner in which economic deprivation mediates the impact of unemployment. More particularly, he argues for the need to relate such analysis to the broader literature on poverty.

Such an analysis has been conducted on the I rish adult sample employing comprehensive measures of income and life-style at the household level. The results are unambiguous. Income measured at the household level bears a clear relationship to G HQ score. It was al so found that this effect operated predominantly through extreme life-style deprivation.

The original $\mathrm{M}$ arienthal conclusion that the deterioration in mental health among members of households affected by unemployment is intimately related to the erosion of economic resources appears to be no less true today (W helan, 1992a, p. 342).

It is not, however, a conclusion to which we are likely to be led by focusing our analysis on the individual incomes of young people. Just as social class seems to be a much less potent indication of life chances for young adults than for the population so it seems that incomes measured at an individual level for young people bear a much less clear-cut relationship to life-style than does household income for the population as a whole. Conclusions relating to the role of such objective factors based on the analysis of young adults are likely to be seriously misleading.

\section{Labour market attitudes}

Young people's perceptions of, and attitudes towards, employment and their own labour market situation can affect psychological well-being in different ways. We will look particularly at young people's analysis of the causes of their own employment situation and their own level of employment commitment.

We measured young people's causal attributions of their employment or unemployment by asking them a series of questions about their views of the main causes of their own 
situation. Respondents were asked "how much of your present situation-i.e. being employed or unemployed-is due to the following factors", and seven different "causes" were allowed. Four scaled responses were allowed. Factor analysis revealed two dimensions of causal attribution amongst respondents, and two attitude scales were constructed which were highly reliable. The two dimensions of causal attributions related to whether these factors were perceived as "personal" or "political/structure" in nature. The items involved were personal casual attributions:

(a) Your own skills and training;

(b) The amount of effort you put into your work;

(c) How good you are at your work and the quality of your skills. and political/structural causal attributions:

(a) Largely a matter of luck;

(b) Ireland's poor economic position in the world;

(c) The policies of the government;

(d) The way in which our society is set up to benefit the poor.

The two dimensions which we identified are two different aspects of causal attribution. However, a summary measures of both the "personal" and "political" attitude scales combined is more illuminating. By constructing corresponding scales and dichotomising it was possible to identify the following four categories:

(a) No clear view of causes of present situation, neither personal nor political structural factors important;

(b) Sees only personal characteristics as important;

(c) Sees both personal and political/structural factors as important causes;

(d) Sees only political/structural factors as important causes.

The reasons given by employed and unemployed respondents for their present situation are set out in Table 4 and show that those in employment clearly see personal factors as the main reasons for their "success". Eighty percent hold this view and less than $2 \%$ focus solely on political/structural factors. In contrast, almost one in two of the unemployed give priority to political/structural causes.

This pattern of results might have been anticipated on the basis of what M irowsky and

Table 4 Percentage distribution of employed and unemployed respondents by type of causal attributions

\begin{tabular}{lcc}
\hline Causal attributions & Employed (\%) & U nemployed (\%) \\
& & \\
\hline N o clear view (1) & $8 \cdot 7$ & 34.8 \\
Personal factors most important (4) & 79.6 & 6.9 \\
Personal and structural factors (3) & $9 \cdot 8$ & 12.4 \\
Structural factors most important (2) & $1 \cdot 8$ & 45.9 \\
\multicolumn{1}{c}{$\%$} & 100 & 100 \\
Total $n$ & 754 & 217 \\
& & $\mathrm{Chi}^{2}=510 \cdot 4$ \\
& & $\mathrm{df}=3$ \\
& & $\mathrm{p}<0.00$ \\
\hline
\end{tabular}


Ross (1990) have labelled the consolation prize theory of alienation which suggests that claiming responsibility for good outcomes enhances self-esteem while accepting responsibility for negative outcomes damages self-esteem. The theory thus holds that for low status people rejecting the role of choice, effort and ability as determinants of outcomes reduces distress ( $H$ yman, 1966). This interpretation of respondents' causal attributions as post-factum rationalisation, designed to maintain positive self images, looks less plausible when we examine the psychological consequences of such attribution.

From Table 5 we can see that, psychologically, the least advantageous set of attributions for the unemployed is that which attributes one's current situation solely to structural factors (over one in three being distressed), followed by personal factors (26\%) and the absence of any clear view on the causes of one's situation ( $23 \%$ being distressed). Since the majority of the unemployed see structural factors as the prime cause of their current situation and this is associated with higher levels of distress there is little evidence of rationalisation. Rather the opposite appears to be the case- the rejection of personal responsibility leads to the highest level of distress while the lowest level is displayed by those who allow for the role of both personal and political/structural factors.

\section{Employment commitment}

The available evidence suggests that those who are highly committed to employment suffer more from unemployment (Banks et al., 1984; W arr et al., 1988; $M$ arsh and A Ivaro, 1990) though the unemployed are likely to have lower levels of commitment. The direction of causality here remains controversial. Furthermore, some have queried if such a lowering of commitment occurs at all. Furlong (1988), for instance, suggests that employment commitment is a learned value which is gained through habituation to work by those who have been unemployed for some time. Hannan and ORiain (1993, pp. 190-191) constructed a measure of employment commitment derived from the extent to which respondents agreed with the following statements:

(a) "Even if I won a great deal of money on the lottery I would still want to work";

(b) "I hate/would hate being/to be on the dole";

(c) "If unemployment benefit/assistance was high enough I would prefer not to work."

From Table 6 it is clear that those in employment had the highest levels of commitment.

Table 5 Percentage above G H Q threshold by respondent's employment status and attribution of causes of present situation

\begin{tabular}{|c|c|c|c|c|c|c|c|c|}
\hline \multirow{3}{*}{$\begin{array}{l}\text { Causal attributions } \\
\text { 1. No clear view } \\
\text { 2. Personal factors most important } \\
\text { 3. Personal and structural factors } \\
\text { 4. Structural factors most } \\
\text { important }\end{array}$} & \multicolumn{6}{|c|}{ Percentage above G HQ threshold ( $\mathrm{n}$ ) } & & \\
\hline & \multicolumn{2}{|c|}{ Employed } & \multicolumn{2}{|c|}{ Unemployed } & \multicolumn{2}{|c|}{ Other } & \multicolumn{2}{|c|}{ T otal } \\
\hline & $\begin{array}{r}15 \cdot 5 \\
5 \cdot 7 \\
10 \cdot 0 \\
7 \cdot 5\end{array}$ & $\begin{array}{r}(66) \\
(600) \\
(74) \\
(150)\end{array}$ & $\begin{array}{l}23 \cdot 4 \\
26 \cdot 1 \\
14 \cdot 7 \\
35 \cdot 1\end{array}$ & $\begin{array}{r}(75) \\
(15) \\
(27) \\
(100)\end{array}$ & $\begin{array}{r}8 \cdot 5 \\
4 \cdot 2 \\
11 \cdot 1 \\
54 \cdot 5\end{array}$ & $\begin{array}{r}(59) \\
(71) \\
(9) \\
(11)\end{array}$ & $\begin{array}{r}18 \cdot 5 \\
6 \cdot 0 \\
10 \cdot 4 \\
33 \cdot 0\end{array}$ & $\begin{array}{l}(200) \\
(686) \\
(110) \\
(126)\end{array}$ \\
\hline \multicolumn{9}{|c|}{$\begin{array}{c}\text { O verall } \mathrm{Chi}^{2}=595 \cdot 7 \\
\mathrm{df}=12 \\
\mathrm{p}<0.001\end{array}$} \\
\hline
\end{tabular}


There al so appears to have been an "habituation" effect in that those likely to have little or no working experience show much lower levels of commitment: the lowest level of commitment being found among those who have never been employed and those in "homeduties" who have withdrawn from the labour force.

W hile the observed differences are modest, and the figures reported are based on small numbers, a relatively clear picture emerged. Those in employment display very high levels of commitment while unemployment is associated with a rather modest reduction in such commitment. Further analysis revealed evidence of an additional reduction for those in long-term unemployment. The strongest evidence, however, is for an "habituation effect". In addition, there is evidence of a significant interaction between employment status and commitment in their impact on psychological distress. From Table 7 it is apparent that those who are highly committed to employment fare best when in employment (with only $6 \%$ above the GHQ threshold) and worst when in unemployment (with close to one in three above the threshold).

The impact of employment commitment should be considered on the context of the evidence that overall levels are extremely high. Sixty percent of the employed and, indeed, $50 \%$ of the unemployed recorded the highest possible commitment scores. The above results suggest that a lower employment commitment level among the unemployed, to the extent that it occurs, can be most plausibly interpreted as an adaptive reaction to unemployment and not a cause of it. There is some psychological benefit for the less

Table 6 Levels of employment commitment by respondent's current labour force status

\begin{tabular}{|c|c|c|c|c|c|c|}
\hline \multirow[b]{2}{*}{$\begin{array}{l}\text { Employment commitment } \\
\text { scale score }\end{array}$} & \multicolumn{5}{|c|}{ Employment status (\%) } & \multirow[b]{2}{*}{ Total } \\
\hline & $\begin{array}{l}\text { W orking for } \\
\text { pay or profit }\end{array}$ & $\begin{array}{l}\text { U nemployed } \\
\text { (lost job) }\end{array}$ & $\begin{array}{l}\text { Seeking } \\
\text { first job }\end{array}$ & Student & $\begin{array}{l}\text { Home } \\
\text { duties }\end{array}$ & \\
\hline $\begin{array}{l}1+2 \text { (Low) } \\
3 \\
4 \text { (High) }\end{array}$ & $\begin{array}{r}2 \cdot 6 \\
34 \cdot 6 \\
62 \cdot 8\end{array}$ & $\begin{array}{r}7 \cdot 1 \\
38 \cdot 8 \\
54 \cdot 1\end{array}$ & $\begin{array}{l}12 \cdot 2 \\
58 \cdot 7 \\
29 \cdot 1\end{array}$ & $\begin{array}{r}4 \cdot 3 \\
47 \cdot 3 \\
48 \cdot 4\end{array}$ & $\begin{array}{l}19 \cdot 8 \\
50 \cdot 9 \\
29 \cdot 3\end{array}$ & $\begin{array}{r}4 \cdot 5 \\
37 \cdot 1 \\
58 \cdot 5\end{array}$ \\
\hline Total & $\begin{array}{l}100 \\
816\end{array}$ & $\begin{array}{l}100 \\
188\end{array}$ & $\begin{array}{r}100 \\
29\end{array}$ & $\begin{array}{c}100 \\
28 \\
\mathrm{Chi}^{2}=4\end{array}$ & $\begin{array}{c}100 \\
57 \\
7, d f=8\end{array}$ & $\begin{array}{r}100 \\
1118 \\
<0.001\end{array}$ \\
\hline
\end{tabular}

Table 7 Psychological distress by employment status and score on employment commitment scale

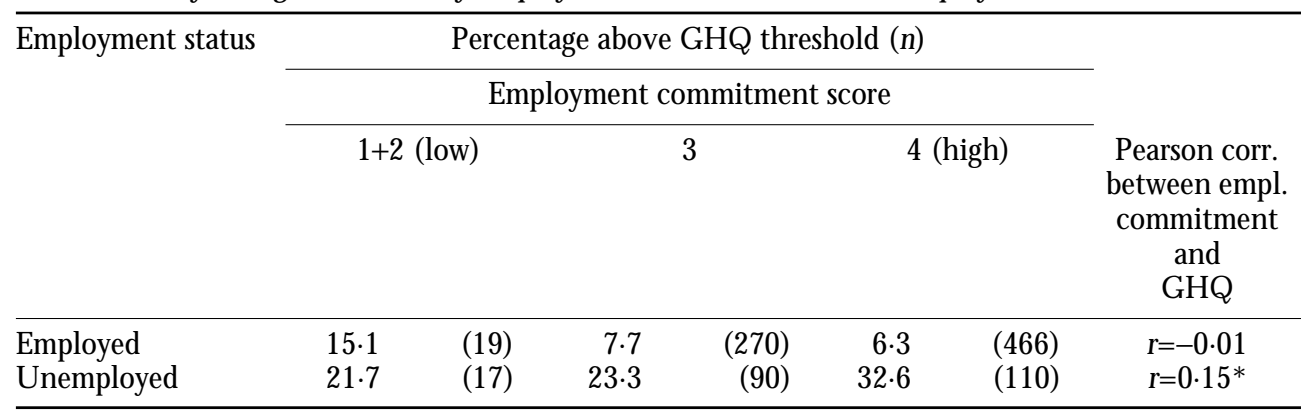

$* p<0.05$. 
committed unemployed, but their level of distress remains very high and is hardly compatible with the choice of unemployment as a preferred life-style. We can find no evidence to support the view that personal choice is a significant factor contributing to young people's unemployment. M ost are either unclear as to the causes of their situation or give priority to structural factors. These beliefs do little to lessen the distressing impact of unemployment.

\section{Feelings of control and mastery}

$M$ any of the labour market attitudes which we have examined so far seem likely to have impact on the young person's psychological well-being through feeling of control over the cause of one's life and the ability to shape one's own future. We can look more directly at these feelings using some questions asked of our sample of school-leavers. Control can be interpreted either as a relatively fixed social-psychological attitude of respondents (M irowsky and Ross, 1986), as a variable set of feelings which essentially mediate or "carry" the impact of stressors on the individual and lead to distress (W helan et al., 1991).

Respondents were asked to express agreement or disagreement on a four-point scale with the following items:

(i) I often feel good about myself and about the things I do.

(ii) I often get discouraged about not doing things as well as I am able to.

(iii) I believe I'm as good as anybody else in any task I set my mind to.

(iv) Sometime I feel there is al most nothing I can do that is needed by anyone.

(v) G enerally I am very satisfied with my life so far.

(vi) I feel I have little control over things about happen to me.

(vii) Sometimes I think that other people have been given an unfair advantage over me. The items were scored so that a high score indicates strong feelings of control. 0 ur results are presented in terms of high and low feelings of control, taking the average of the scale as the dividing point.

The unemployed are much more likely to feel that they have little control over their lives: $35 \%$ score below the mean compared to $15 \%$ of the unemployed. W e cannot settle the issue of causality with our data but it seems most plausible that the experience of becoming and remaining unemployed reduces feelings of personal control. What is absolutely clear however is that low feelings of control are associated with high levels of psychological distress. From Table 8 it is evident that "control" partly explains the damaging effects of unemployment but also has an equally important independent effect. Strong feelings of personal control and efficacy do help greatly in making the experience of unemployment less distressing (reducing the number above the GHQ threshold from over two in five to one in five).

Table 8 The effects of personal control/mastery on psychological distress by employment status

\begin{tabular}{|c|c|c|c|c|c|}
\hline \multirow{3}{*}{$\begin{array}{l}\text { Employment } \\
\text { status }\end{array}$} & \multicolumn{4}{|c|}{ Percentage above G HQ threshold (n) } & \\
\hline & \multicolumn{4}{|c|}{ Feelings of control } & \\
\hline & \multicolumn{2}{|c|}{ High } & \multicolumn{2}{|c|}{ Low } & \\
\hline $\begin{array}{l}\text { Employed } \\
\text { U nemployed } \\
\text { T otal }\end{array}$ & $\begin{array}{r}5 \cdot 0 \\
20 \cdot 3 \\
7 \cdot 6\end{array}$ & $\begin{array}{l}(637) \\
(140) \\
(914)\end{array}$ & $\begin{array}{l}18 \cdot 6 \\
41 \cdot 8 \\
28 \cdot 7\end{array}$ & $\begin{array}{r}(115) \\
(77) \\
(219)\end{array}$ & $\begin{array}{l}C h i_{2}=46.1 ; d f=1 ; p<0.001 \\
C h i^{2}=12.2 ; d f=1 ; p<0.001\end{array}$ \\
\hline
\end{tabular}


The introduction of sense of control into multivariate analysis has minimal effects on the relationship between other independent variables and psychological distress. The outstanding exception is unemployment; where the effect of the unemployment by social class interaction term becomes insignificant. It would appear then that the effects of unemployment, even for those from working class backgrounds, are fully mediated through their social-psychological consequences- on "dysfunctional" causal attributions, employment commitment and, particularly, low feelings of control. If feelings of control is one of the social-psychological mechanisms whereby distress is accentuated or ameliorated, and not a permanent feature of personality, then the behaviour of the unemployment/class interaction would suggest that it is an increasingly important mechanism as we descend the class hierarchy. The finding is consistent with results reported by Whelan (1992b) in relation to the adult population that increments of control have their most dramatic effect among those with low status and resources.

\section{Conclusions}

In this paper we have examined some of the main factors which increase levels of distress among young people, particularly the young unemployed. The experience of unemployment itself is the main factor contributing to increased levels of distress. The clear-cut relationships which are found between social class and income at the overall population level are not apparent among the sample of young adults. The most plausible hypothesis is that they will emerge over time as those who remain trapped at the bottom of the class hierarchy. The fact that the impact of unemployment is greatest among those from working class backgrounds and that this effect is significantly mediated by levels of fatalism suggest that this is also the "working hypothesis" of those from working class backgrounds.

The impact of unemployment is mediated by crucial social-psychological variables which also have independent effects. Of particular relevance are greater fatalism, passivism and beliefs that impersonal economic and political forces control the economic environment and employment chances. Feelings of loss of control and decline in feelings of personal efficacy increase significantly with unemployment, and, when present, significantly increase levels of distress. Both of these latter social-psychological processes partly mediate (or even express) the distress-causing effects of unemployment, though only partly explaining them away. $\mathrm{N}$ ot all unemployed people become fatalistic, feeling hopeless in the grasp of external circumstances, and such a retention of personal confidence and control significantly reduces distress levels. However, the retention of strong feelings of employment commitment does not help. A Ithough these decline with length of unemployment the great majority of the unemployed retain strong feelings of work commitment and these paradoxically increase levels of distress. So, intervention designed to increase such commitments without increasing chances of actual employment could do significant damage. $\mathrm{On}$ the other hand, interventions which increase feelings of personal control and efficacy and reduce fatalism could significantly reduce the level of psychological and social stress suffered by the unemployed.

U nemployed young people, therefore, suffer a series of deprivations associated with their unemployment-economic deprivation and, in many cases, a set of beliefs about control over their own situation which are deeply distressing. While these young people are somewhat alienated from their contemporaries and adult society, they do not appear to 
form "subcultures" which develop new, psychologically protective social norms. In fact, they hold closely to more general social norms and standards about work, despite their distressing effects; but they recover quickly in terms of well-being if re-employed. In short these are not "problem young people" but young people who have problems inflicted on them, and suffer extremely damaging consequences.

\section{References}

Banks, M. H., U llah, P. and W arr, P. (1984). U nemployment and less qualified urban young people. Employment $\mathrm{G}$ azette, 2, 343-346.

Breen, R. (1991). Education, Employment and Training in the Youth Labour M arket. General Research Series N 0. 152. Dublin: The Economic and Social R esearch Institute.

Breen, R., H annan, D. F., Rottman, D. B. and W helan, C. T. (1990). U nderstanding Contemporary I reland: State, C lass and D evelopment in the Republic of I reland. London: M acmillan.

Callan, T., N olan, B., W helan, B., Hannan, D. and Creighton, S. (1989). Poverty and the Social W elfare System in I reland. General Research Series, N 0. 146. Dublin: The Economic and Social Research Institute.

Donovan, A . and O ddy, M. (1982). Psychological aspects of unemployment: an investigation into the emotional and social adjustment of school leavers. Journal of A dolescence, 5, 15-30.

Feather, N. and O'Brien, G. E. (1986). A longitudinal study of the effects of employment and unemployment on school leavers. Journal of $O$ ccupational Psychology, 5, 121-144.

Fox, W . (1990). Social class, mental illness and social mobility. Journal of $\mathrm{H}$ ealth and Social Behaviour, 31, 344-353.

Fryer, D. (1986). Employment deprivation and personal agency during unemployment. Social Behaviour, 1, 3-23.

Fryer, D. (1990). The mental health costs of unemployment, toward a social psychological concept of poverty. B ritish Journal of C linical and Social Psychiatry, 7 (4), 164-175.

Furlong, A . (1988). But they don't want to work, do they? U nemployment and work ethics among young people in Scotland. In Education and the Youth Labour M arket, Raffe, D. (Ed.). London: Falmer.

G oldberg, D. B. (1972). T he D etection of P sychiatric Illness by Q uestionaire. London: O xford U niversity Press.

Gurney, R. M. (1980). The effects of unemployment on the psycho-social development of school leavers. Journal of $O$ ccupational Psychology, 53, 205-213.

$\mathrm{H}$ annan, D. F. and ORiain, S. (1993). Pathways to A dulthood in Ireland: C auses and C onsequences of Success and Failure in T ransitions A mong Irish Youth. General Research Series, N 0. 161. Dublin: The Economic and Social Research Institute.

H annan, D. F. and Shorthall, S. (1991). The Quality of Their Education: School Leavers' Views of Educational $O$ bjectives and $O$ utcomes. General Research Series, N o. 153. Dublin: The Economic and Social Research Institute.

H obbs, P. R., Ballinger, G. B., M cClure, A ., M artin, B. and G reenwood, G . (1985). Factors associated with psychiatric morbidity in men: a general practice survey. A cta Psychiatrica Scandinavica, 71, 281-286.

Hyman, H. H. (1966). The value systems of different social classes: a social psychological contribution to the analysis of stratification. In Social Stratification in Comparative Perspective, 2nd Edn, Bendix, R. and Lipset, S. M. (Eds). N ew York: Free Press.

Jackson, P. R., Stafford, E. M., Banks, M. H. and W arr, P. B. (1983). U nemployment and psychological distress in young people: the moderating role of employment commitment. Journal of A pplied Psychology, 68, 525-535.

Kessler, R. (1979). Stress, Social Status and Psychological Distress. Journal of $\mathrm{H}$ ealth and Social Behaviour, 20, 259-272 
Kessler, R. C. and Cleary, P. D. (1980). Social class and psychological distress. A merican Sociological Review, 45, 463-478.

Kessler, R. C., Blake Turner, J. and House, J. S. (1989). U nemployment, reemployment and emotional functioning in a community sample. A merican Sociological Review, 54, 648-657.

Liem, R. (1987). The psychological consequences of unemployment: a comparison of findings and definitions. Social Research, 55, 321-353.

Marsh, C. and Alvaro, J. L. (1990). A cross-cultural perspective on the social and psychological distress caused by unemployment: a comparison of Spain and the U nited Kingdom. European Sociological Review, 6 (3), 237-255.

M cLeod, J. D. and Kessler, R. C. (1990). Socioeconomic status differences in vulnerability to undesirable life events. Journal of $\mathrm{H}$ ealth and Social Behaviour, 31 (2), 161-172.

M cRae, S. (1987). Young and Jobless: The Social and Personal Consequences of Youth U nemployment. London: Policy Studies Institute.

M irowsky, J. and Ross, C. E. (1986). Social patterns of distress. A nnual Review of Sociology, 12, 23-45.

M irowsky, J. and Ross, C. E. (1990). The consolation prize theory of alienation. A merican Journal of Sociology, 95 (6), 1505-1535.

O 'Brien, G. E. (1986). Psychology of W ork and U nemployment. Chichester: John W iley and Sons.

Pearlin, L. T., M enaghan, E., Lieberman, M. and M ullan, J. T. (1981). The stress process. Journal of $H$ ealth and Social Behaviour, 22, 337-351.

Ullah, P. (1990). The association between income, financial strain and psychological well-being among unemployed youths. Journal of 0 ccupational Psychology, 63, 317-330.

V aillant, G. and Vaillant, C. (1981). N atural history of male psychological health $\mathrm{X}$ : work as a predictor of positive mental health. A merican Journal of Psychiatry, 136, 1433-1440.

W arr, P. B. (1985). Twelve questions about unemployment and health. In $\mathrm{N}$ ew A pproaches to Economic Life, Roberts, B., Finnegan, R. and Gaillie, D. (Eds). Manchester: M anchester U niversity Press.

W arr, P. (1987). W ork, U nemployment and M ental H ealth. O xford: Clarendon Press.

W arr, P. and Jackson, P. (1984). Men without jobs: some correlates of age and length of unemployment. Journal of 0 ccupational Psychology, 57, 77-85.

W arr, P., Jackson, P. and Banks, M. (1988). U nemployment and mental health: some British studies. Journal of Social Issues, 44 (4), 47-68.

W helan, C. T. (1992a). The role of income, life style deprivation and financial strain in mediating the impact of unemployment and psychological strain. Journal of 0 ccupational and 0 rganisational Psychology, 65, 331-341.

W helan, C. T. (1992b). The impact of realistic and illusory control on psychological distress: a test of the model of instrumental realism. The E conomic and Social Review, 23, 4.

Whelan, C. T. (1994). Social class, unemployment and psychological distress. European Sociological Review, 10 (1), 49-61.

W helan, C. T. (1996). M arginalization, deprivation and fatalism in the Republic of Ireland: class and underclass perspectives. European Sociological Review, 12, 1.

Whelan, C. T., H annan, D. F. and Creighton, S. (1991). U nemployment, Poverty and Psychological Distress. G eneral Research Series N 0. 150. Dublin: The Economic and Social Research Institute.

W inefield, A. H. and Tiggemann, M. (1989a). Job loss vs. failure to find work as psychological stressors in the young unemployed. Journal of 0 ccupational Psychology, 62 (1), 79-85.

W inefield, A. H. and Tiggemann, M. (1989b). U nemployment duration and affective well-being in the young. Journal of 0 ccupational P sychology, 62, 327-336. 